\title{
The impact of quitting smoking on symptoms of chronic bronchitis: results of the Scottish Heart Health Study
}

\author{
C A Brown, I K Crombie, W C S Smith, Hugh Tunstall-Pedoe
}

\begin{abstract}
Scotland has high rates of death from diseases of the respiratory system and high rates of smoking, especially among women. Data on self reported smoking and prevalence of chronic cough and chronic phlegm among 10359 men and women aged 40-59 years were obtained from the Scottish Heart Health Study. Overall, current cigarette smokers had rates of chronic cough and chronic phlegm four to five times those of never smokers after standardisation for age $(32.3 \% v 6.5 \%$ for men and $24 \% v 5.5 \%$ for women for chronic cough; $31 \% v$ $8.3 \%$ for men and $21 \% v 5 \cdot 5 \%$ for women for chronic phlegm). Ex-smokers' symptom rates were a little above those of never smokers and were significant for chronic cough among women and chronic phlegm among men. Men had higher symptom rates than women and this was true for smokers, ex-smokers, and never smokers. The higher rates among men could not be explained by higher cotinine concentrations. Tests to detect "deceivers" among ex-smokers and never smokers using biochemical validation suggested that $87(1.5 \%)$ respondents were in fact smoking; they were excluded from analyses. There were substantially lower rates of chronic cough and chronic phlegm within a year of stopping smoking, and two to four years after stopping $89-99 \%$ of the difference between current smokers and never smokers was accounted for (99\% and $93 \%$ for men and women with chronic cough, $96 \%$ and $89 \%$ for men and women with chronic phlegm). Even 10 years after stopping, rates of symptoms among ex-smokers remained a little above those of never smokers (except for women with chronic phlegm), though these differences were not statistically significant. Former heavy smokers continued to have rates of chronic cough and chronic phlegm that were higher than those of former light and moderate smokers (though not significantly so). These are cross sectional data, but they emphasise the importance for chronic bronchitis symptoms of giving up cigarette smoking, though the amount previously smoked continues to exert a small influence.
\end{abstract}

Chronic bronchitis remains a major cause of morbidity and mortality in the developed world. ${ }^{1}$ Scotland has one of the highest rates of death from diseases of the respiratory system in the world. ${ }^{2}$ Smoking is well known as a major risk factor for chronic bronchitis ${ }^{3-5}$ and is now regarded as the main cause of chronic bronchitis and respiratory disease in the United Kingdom. ${ }^{6}$ Mortality from chronic bronchitis has been falling in the $\mathrm{UK},{ }^{1}$ as have smoking rates. ${ }^{7}$

Two major symptoms of chronic bronchitis are chronic cough and chronic phlegm, and a decrease in chronic cough and chronic phlegm after quitting smoking has been reported. ${ }^{8}$ The rates of chronic cough and chronic phlegm among ex-smokers have been looked at in some large studies ${ }^{89}$ but these have not investigated the frequency of these symptoms over time since quitting for both men and women, or included objective validation of the claim to have given up smoking. One problem in the interpretation of the results of these studies is the possibility of deception among declared ex-smokers and never smokers, which could lead to higher rates of chronic bronchitis among apparent non-smokers. This paper uses data from a large cross sectional survey, the Scottish Heart Health Study, ${ }^{10}$ and looks at chronic cough and chronic phlegm and their relation to smoking history, which has been verified with biochemical measurements.

\section{Methods}

POPULATION SAMPLE

The data used in this study of chronic bronchitis symptoms were taken from the Scottish Heart Health Study, which was set up to investigate the high incidence of coronary heart disease in Scotland. ${ }^{1011} \mathrm{~A}$ sample of 10359 men and women aged 40-59 years was taken from 22 districts throughout Scotland. The 22 districts were selected to provide a good geographical spread and a range of urban-rural characteristics and coronary mortality rates. Each subject was sent a questionnaire to complete at home and an appointment to attend a survey clinic for examination. The data presented in this paper are based on replies to questions taken from the British Medical Research Council respiratory questionnaire $^{12}$ and the World Health Organisation standard smoking questions ${ }^{13}$ with some additional questions on smoking. 


\section{MEASUREMENTS}

Expired air carbon monoxide was measured and a blood sample was taken for thiocyanate and cotinine estimation. Carbon monoxide was measured with a model 2000 portable carbon monoxide Ecolyser (Analysis Automation Ltd) or an EC50 carbon monoxide monitor (Bedfont Technical Instruments Ltd). A comparison of the two machines showed very similar results. ${ }^{14}$ Serum thiocyanate concentration was determined with a COBAS Bio analyser and serum cotinine was analysed by gas-liquid chromatography. ${ }^{15}$

\section{DEFINITION OF TERMS}

Chronic bronchitis symptoms are defined as follows. Chronic cough: Cough first thing in the morning and/or at any time during the day or night for as much as three months each year. Chronic phlegm: Bringing up phlegm from the chest first thing in the morning and/or at any time during the day or night for as much as three months each year.

$A$ cigarette smoker is one who describes himself currently as a regular or occasional cigarette smoker and an ex-smoker is someone who was a cigarette smoker. The groupings for cigarette consumption among current smokers are by cotinine quartile $(\mathrm{nmol} / \mathrm{l})$ as follows: I < 171, II 171.01-261, III 261.01357 , and IV $>357$. The groupings for cigarette consumption/day among ex-smokers are $<19$ and $\geqslant 20 .{ }^{9}$ We refer to these categories as light-moderate and heavy.

A deceiver is a declared ex-smoker or never smoker who satisfies at least two of the following criteria: (1) a carbon monoxide concentration above $6 \mathrm{ppm}$; (2) a blood thiocyanate concentration above $63.4 \mu \mathrm{mol} / 1$; (3) a blood cotinine concentration above $20.0 \mathrm{nmol} / \mathrm{l}$ ( $M$ Woodward and $\mathrm{H}$ Tunstall-Pedoe, unpublished findings).

\section{STATISTICAL METHODS}

A $t$ test was used to test the significance of the differences between group means. A test for differences in proportions examined differences between rates of choronic cough in various groups and rates of chronic phlegm in various groups. The age standardised $95 \%$ confidence limits for the odds ratios were calculated by the Mantel-Haenszel method. ${ }^{16}$ The age standardised $95 \%$ confidence limits for each category of subjects giving up smoking were calculated. ${ }^{17}$

\section{Results}

\section{EFFECTS OF CURRENT SMOKING HABIT}

Excluding 1042 cigar and pipe smokers and 70 individuals whose smoking habit was unknown left 9247 subjects in the study. Of these, $38.7 \%$ (1602 men and 1974 women) were current cigarette smokers, $25.6 \%$ (1301 men and 1062 women) were declared ex-smokers, and $35.8 \%$ (1173 men and 2135 women) claimed to have never smoked cigarettes.

Table 1 shows the rates of chronic cough and chronic phlegm by smoking habit. These rates and all other rates presented were age standardised on the basis of the four five year age groups (40-44, 45-49, 50-54, 55-59 years) used in the Scottish Heart Health Study, because there is an age trend among current cigarette smokers, ex-cigarette smokers, never smokers, and deceivers to have higher chronic respiratory rates in the older age groups $(50-54$, 55-59 years). Eighty seven subjects, 68 declared ex-smokers and 19 declared never smokers, were considered to be deceivers. Among the men deceivers had significantly higher rates of chronic cough ( $\mathrm{p}<0.05 v$ exsmokers and never smokers) and chronic phlegm ( $\mathrm{p}<0.01 v$ ex-smokers, $\mathrm{p}<0.001 v$ never smokers). Among the women none of the differences was significant. Deceivers were excluded from further analyses. Current cigarette smokers had the highest rates of both chronic cough and chronic phlegm ( $p<0.001$ $v$ ex-smokers and never smokers), those who had never smoked having the lowest rates. The rates for ex-cigarette smokers were a little above those who had never smoked ( $p<0.05$ for chronic cough among women and chronic phlegm among men). In each category the symptom rates among men were higher than those among women.

In the following analyses the results for chronic phlegm are shown. The patterns are

Table 1 Prevalence of chronic respiratory symptoms by age according to smoking among men and women (percentages with numbers of positive subjects in parentheses)

\begin{tabular}{|c|c|c|c|c|c|c|c|c|}
\hline & \multicolumn{4}{|l|}{ Men } & \multicolumn{4}{|l|}{ Women } \\
\hline & $\begin{array}{l}\text { Current } \\
\text { smoker } \\
(n=1602)\end{array}$ & $\begin{array}{l}\text { Ex- } \\
\text { smoker } \\
(n=1301)\end{array}$ & $\begin{array}{l}\text { Never } \\
\text { smoker } \\
(n=1173)\end{array}$ & $\begin{array}{l}\text { Deceiver } \\
(n=38)\end{array}$ & $\begin{array}{l}\text { Current } \\
\text { smoker } \\
(n=1974)\end{array}$ & $\begin{array}{l}\text { Ex- } \\
\text { smoker } \\
(n=1062)\end{array}$ & $\begin{array}{l}\text { Never } \\
\text { smoker } \\
(n=2135)\end{array}$ & $\begin{array}{l}\text { Deceiver } \\
(n=49)\end{array}$ \\
\hline $\begin{array}{l}\text { Chronic cough } \\
40-44 \\
45-49 \\
50-54 \\
55-59 \\
\text { Age standardised }\end{array}$ & $\begin{array}{l}23 \cdot 7(90) \\
33 \cdot 2(125) \\
32 \cdot 2(129) \\
39 \cdot 9(152) \\
32 \cdot 3(496)\end{array}$ & $\begin{array}{c}5 \cdot 6(14) \\
5 \cdot 3(13) \\
8 \cdot 3(28) \\
10 \cdot 2(42) \\
7 \cdot 4 \dagger(97)\end{array}$ & $\begin{array}{l}4 \cdot 0(12) \\
7 \cdot 0(19) \\
7 \cdot 7(25) \\
7 \cdot 6(18) \\
6 \cdot 6+(74)\end{array}$ & $\begin{array}{r}9 \cdot 1(1) \\
25 \cdot 0(1) \\
18 \cdot 2(2) \\
41 \cdot 7(5) \\
23 \cdot 5(9)\end{array}$ & $\begin{array}{l}23.4(118) \\
23.9(117) \\
25.3(112) \\
25.8(115) \\
24.6(462)\end{array}$ & $\begin{array}{l}5 \cdot 2(14) \\
8 \cdot 4(18) \\
6 \cdot 3(15) \\
8 \cdot 4(23) \\
7 \cdot 0^{\star}(70)\end{array}$ & $\begin{array}{l}3 \cdot 6(18) \\
6 \cdot 1(30) \\
5 \cdot 8(34) \\
5 \cdot 3(26) \\
5 \cdot 2(108)\end{array}$ & $\begin{array}{r}6.7(1) \\
0.0(0) \\
0.0(0) \\
11 \cdot 1(2) \\
4.4(3)\end{array}$ \\
\hline $\begin{array}{l}\text { Chronic phlegm } \\
40-44 \\
45-49 \\
50-54 \\
55-59 \\
\text { Age standardised }\end{array}$ & $\begin{array}{l}24 \cdot 5(94) \\
30 \cdot 9(116) \\
31 \cdot 6(127) \\
36 \cdot 8(142) \\
31 \cdot 0(479)\end{array}$ & $\begin{array}{l}10 \cdot 1(25) \\
8 \cdot 6(21) \\
12 \cdot 8(43) \\
11 \cdot 4(46) \\
10 \cdot 8^{\star}(135) \dagger \dagger\end{array}$ & $\begin{array}{c}5 \cdot 0(15) \\
8 \cdot 5(23) \\
8 \cdot 2(27) \\
11 \cdot 0(26) \\
8 \cdot 2 \dagger+\dagger(91)\end{array}$ & $\begin{array}{l}9 \cdot 1(1) \\
50 \cdot 0(2) \\
27 \cdot 3(3) \\
58 \cdot 3(7) \\
36 \cdot 0(13)\end{array}$ & $\begin{array}{l}19 \cdot 4(99) \\
20 \cdot 7(101) \\
21 \cdot 0(95) \\
25 \cdot 7(115) \\
21 \cdot 7(410)\end{array}$ & $\begin{array}{l}4 \cdot 5(12) \\
7 \cdot 9(17) \\
5 \cdot 5(13) \\
8 \cdot 7(24) \\
6 \cdot 6(66)\end{array}$ & $\begin{array}{l}4 \cdot 8(24) \\
5 \cdot 9(29) \\
6 \cdot 3(36) \\
5 \cdot 0(25) \\
5 \cdot 5(114)\end{array}$ & $\begin{array}{r}20.0(3) \\
0.0(0) \\
0.0(0) \\
11 \cdot 1(2) \\
7.9(5)\end{array}$ \\
\hline
\end{tabular}

The test for differences in proportions is between $(1)$ ex-smokers $v$ never smokers $\left({ }^{\star} p<0.05\right)$; (2) deceivers $v$ ex-smokers and deceivers $v$ never smokers $(\dagger p<0.05,+\dagger p<0.01,+\dagger+p<0.001)$ 
Figure 1 Current smokers: age standardised rates of chronic phlegm and mean blood cotinine (cot) concentrations among men and women by cotinine quartile (see under "Methods"). The test comparison is made in each cotinine quartile between male and female cotinine means (number in parentheses) $(\star \star \star p<$ $0.001)$ and chronic phlegm rates $\left({ }^{\star} p<0.01\right)$

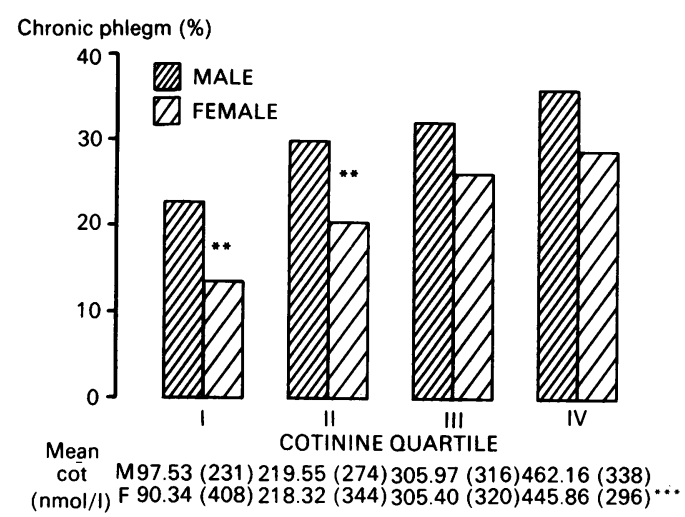

similar, though less pronounced, for chronic cough.

\section{CORRELATIONS WITH SERUM COTININE}

A strong dose-response relationship was found between the frequency of reported chronic phlegm and the level of cigarette smoking (as measured by cotinine quartile) among current cigarette smokers (fig 1). Men had higher rates of respiratory symptoms than women at each level of smoking ( $p<0.01$ for quartiles I and II). The mean values for cotinine in each quartile were very similar for men and women and differed significantly only in the upper quartile, men having the higher mean $(\mathrm{p}<0.001)$. Similar results were seen with carbon monoxide and thiocyanate quartiles.

The odds ratios for chronic cough and chronic phlegm in men and women for each cotinine quartile compared with the never smokers are shown in table 2. There is a clear dose-response effect with higher odds ratios in each successive cotinine quartile except for chronic cough among women, where the rate in the upper quartile of chronic cough is lower than that in the third quartile. This doseresponse effect was more pronounced for chronic cough than for chronic phlegm. The odds ratios are similar for men and women in each corresponding quartile for both chronic cough and chronic phlegm.

\section{EFFECTS OF GIVING UP SMOKING}

Figure 2 shows the decrease in rates of reported chronic phlegm by the length of time since giving up smoking. For comparison, the rates

Table 2 Odds ratios (adjusted for age) for chronic cough and chronic phlegm by cotinine quartile among male and female smokers compared with never smokers

\begin{tabular}{|c|c|c|c|c|}
\hline \multirow[b]{2}{*}{$\begin{array}{l}\text { Cotinine } \\
\text { quartile }^{\star}\end{array}$} & \multicolumn{2}{|c|}{ Chronic cough } & \multicolumn{2}{|c|}{ Chronic phlegm } \\
\hline & $\begin{array}{l}\text { Odds } \\
\text { ratio }\end{array}$ & $\begin{array}{l}95 \% \text { confidence } \\
\text { limits }\end{array}$ & $\begin{array}{l}\text { Odds } \\
\text { ratio }\end{array}$ & $\begin{array}{l}95 \% \text { confidence } \\
\text { limits }\end{array}$ \\
\hline \multicolumn{5}{|l|}{ Men } \\
\hline I & $3 \cdot 92$ & $(3 \cdot 59,4 \cdot 28)$ & $3 \cdot 25$ & $(3.00,3.52)$ \\
\hline II & $6 \cdot 24$ & $(5 \cdot 83,6.68)$ & $4 \cdot 80$ & $(4 \cdot 52,5 \cdot 10)$ \\
\hline III & 6.35 & $(5.98,6.68)$ & $5 \cdot 32$ & $(5.04,5.62)$ \\
\hline IV & $9 \cdot 08$ & $(8 \cdot 58,9 \cdot 60)$ & $6 \cdot 28$ & $(5.97,6.62)$ \\
\hline \multicolumn{5}{|l|}{ Women } \\
\hline I & 3.45 & $(3 \cdot 26,3 \cdot 66)$ & $2 \cdot 68$ & $(2 \cdot 51,2 \cdot 86)$ \\
\hline II & 5.06 & $(4 \cdot 80,5 \cdot 34)$ & $4 \cdot 38$ & $(4 \cdot 16,4 \cdot 62)$ \\
\hline III & $8 \cdot 60$ & $(8 \cdot 17,9.05)$ & $6 \cdot 12$ & $(5 \cdot 79,6 \cdot 47$ \\
\hline IV & $7 \cdot 47$ & $(7 \cdot 04,7.92)$ & 6.85 & $(6 \cdot 49,7 \cdot 24)$ \\
\hline
\end{tabular}

$\star_{\mathrm{I}}: \leqslant 171$; II: 171·01-261; III: 261·01-357; IV: > $357(\mathrm{nmol} / \mathrm{l})$.

for chronic phlegm among men and women who were current cigarette smokers are shown. Of the difference in rates between current smokers and never smokers among men and women, $39.6 \%$ was accounted for within a year of quitting smoking among men and $60 \%$ among women. Two to four years after quitting further reductions of $56.4 \%$ (among men) and $29 \%$ (among women) in the difference were seen. Even many years after quitting smoking, however, the rate of chronic phlegm production among male ex-smokers was still higher than the rate among never smokers. The rate for female ex-smokers many years after giving up smoking was lower than the rate for never smokers. The rates of chronic cough, for both men and women, are still higher for ex-smokers than for never smokers, even many years after giving up. None of these differences, however, between ex-smokers who had quitted 10 or more years before and never-smokers, nor any of the differences between groups according to length of time since quitting beyond one year, reached significance.

Table 3 looks at the effect of time since giving up on the frequency of chronic bronchitis symptoms by the number of cigarettes excigarette smokers had smoked daily. The daily consumption is split into light-moderate and heavy smokers. Men had tended to smoke more than women. Most men in the lower consumption group had given up more than 10 years ago. Even after 10 years, for both men and women, there was a higher rate of chronic cough and chronic phlegm in the higher consumption group, though this trend was not significant.

\section{Discussion}

This study confirms the high rates of chronic cough and chronic phlegm associated with cigarette smoking in a country with a high mortality from chronic bronchitis. The study

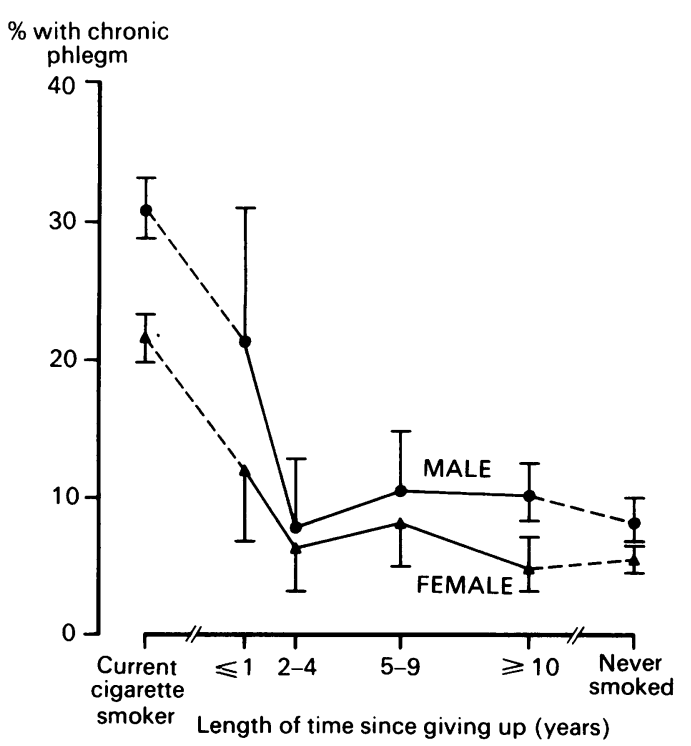

Figure 2 Age standardised rates (with 95\% confidence limit estimates) of chronic phlegm production among male and female ex-smokers by length of time since they gave up smoking. 
Table 3 Chronic bronchitis symptoms in ex-smokers according to time since quitting and previous cigarette consumption (percentages with numbers of subjects in parentheses; rates standardised for age)

\begin{tabular}{|c|c|c|c|c|c|c|c|c|}
\hline & \multicolumn{4}{|l|}{ Men } & \multicolumn{4}{|l|}{ Women } \\
\hline & \multicolumn{2}{|l|}{$<20 /$ day } & \multicolumn{2}{|l|}{$\geqslant 20 /$ day } & \multicolumn{2}{|l|}{$<20 /$ day } & \multicolumn{2}{|l|}{$\geqslant 20 /$ day } \\
\hline & $\begin{array}{l}<10 y \\
\text { since } \\
\text { quitting } \\
(n=130)\end{array}$ & $\begin{array}{l}\geqslant 10 y \\
\text { since } \\
\text { quitting } \\
(n=274)\end{array}$ & $\begin{array}{l}<10 y \\
\text { since } \\
\text { quitting } \\
(n=410)\end{array}$ & $\begin{array}{l}\geqslant 10 y \\
\text { since } \\
\text { quitting } \\
(n=442)\end{array}$ & $\begin{array}{l}<10 y \\
\text { since } \\
\text { quitting } \\
(n=250)\end{array}$ & $\begin{array}{l}\geqslant 10 y \\
\text { since } \\
\text { quitting } \\
(n=350)\end{array}$ & $\begin{array}{l}<10 y \\
\text { since } \\
\text { quitting } \\
(n=224)\end{array}$ & $\begin{array}{l}\geqslant 10 y \\
\text { since } \\
\text { quitting } \\
(n=136)\end{array}$ \\
\hline $\begin{array}{l}\text { Chronic cough } \\
\text { Chronic phlegm }\end{array}$ & $\begin{array}{l}4 \cdot 1(6) \\
8 \cdot 3(11)\end{array}$ & $\begin{array}{l}5 \cdot 7(19) \\
9 \cdot 2(25)\end{array}$ & $\begin{array}{l}9 \cdot 5^{\star}(39) \\
13 \cdot 3(54)\end{array}$ & $\begin{array}{r}8.0(37) \\
11.9(53)\end{array}$ & $\begin{array}{l}7 \cdot 7(18) \\
8 \cdot 4(20)\end{array}$ & $\begin{array}{l}5 \cdot 9(20) \\
4 \cdot 4(16)\end{array}$ & $\begin{array}{l}8 \cdot 1(18) \\
8 \cdot 7(19)\end{array}$ & $\begin{array}{l}7 \cdot 2(9) \\
5 \cdot 1(7)\end{array}$ \\
\hline
\end{tabular}

The test for differences between proportions is between $(1)<20 /$ day $v \geqslant 20 /$ day $\left({ }^{\star} \mathrm{p}<0.05\right)$; (2) $<10$ years since quitting $v \geqslant 10$ years since quitting (no differences significant).

also shows the rapidity with which these symptoms of chronic bronchitis disappear after cessation of smoking and the much lower rates among ex-smokers than among current smokers.

The accuracy of self reporting of respiratory symptoms may be a cause of concern. The Medical Research Council respiratory questionnaire is a widely used and reliable method for ascertaining respiratory symptoms $\mathrm{s}^{18}$ and the replies to the questions on phlegm have been shown to relate well to the phlegm expectorated. ${ }^{20}$ "Deceivers," who might have been occasional smokers, were removed, so this study excludes subjects who might have biased the results.

This study confirms the observation that giving up smoking has a major effect on the frequency of chronic bronchitis symptoms, even one year after quitting. The finding that the rates (except for that of chronic phlegm production among women) never quite reach those of the never smokers is confirmed by Beck et $a l,{ }^{3}$ who in a six year follow up found levels of usual cough and phlegm still above those of the never smokers, though the rates for men were quite close. Hammond, ${ }^{21}$ in a study of cough among men only, found the rates to be the same for ex-smokers as for never smokers after four years.

The number of cigarettes previously smoked daily by ex-smokers continues to exert an influence on the frequency of chronic bronchitis symptoms. This is more strongly related to chronic phlegm in our study. The effect is strongest in the first year, but even after many years those who were heavier smokers have higher rates. Hammond ${ }^{21}$ looked at this effect on cough and found little difference between lightmedium and heavy smokers, except among those who had given up in the last year, where heavier smokers had higher rates of cough. His findings were for simple cough and not chronic cough as in our study, and were only for men. The sales weighted tar yield of all brands of manufactured cigarettes smoked has more than halved in the past 30 years. ${ }^{22}$ Possibly those subjects who smoked high tar cigarettes have high rates of chronic cough and chronic phlegm, even long after quitting smoking.

The study confirms that men have higher frequencies of chronic bronchitis symptoms than women ${ }^{53}$ (in some studies, however, this has been true only for chronic phlegm). ${ }^{39}$ Women multiplied their rate of symptoms through smoking at a rate similar to that of men, but their baseline prevalence rate was lower. Our findings show that for cigarette smokers the cotinine means in each cigarette dose category (cotinine quartile) are similar for men and women except in the upper quartile. This finding that men with cotinine concentrations similar to those of women still have higher rates of chronic cough and chronic phlegm indicates that another factor among men may control their higher rates. The strong doseresponse relationship among current smokers with higher rates of chronic cough and chronic phlegm among the heavier smokers in our study is in accordance with the findings of other studies. ${ }^{921}$ 23-26

The frequency of chronic bronchitis symptoms for current cigarette smokers in this study are four to five times those of never smokers. This is similar to previous findings that rates for cigarette smokers were three to five times those of never smokers. ${ }^{91232426}$ The rates of chronic cough and chronic phlegm among ex-smokers are normally between those of never smokers and of current smokers; but in the case of men in the study by Higgins $e t a l^{23}$ and groups in the study of Friedman $e t a l^{\beta}$ the rates are lower than those of the never smokers. In our study and most others ${ }^{52124} 25$ the rates for ex-smokers are closer to those of the never smokers, but occasionally they are closer to those of the current smokers. ${ }^{27} \mathrm{~A}$ cohort study would have been able to verify whether the apparent effect of giving up smoking on the rates is genuine, or whether those who gave up had been different in their smoking habits from those who continued to smoke.

In conclusion, even one year after quitting smoking the rates of chronic cough and chronic phlegm are below those of most cigarette smokers. Even after 10 years, however, the rates are still above those of never smokers except for women with chronic phlegm, though these differences at this time are not significant. Those who had smoked heavily have higher rates even after some years than those who had been light or moderate smokers, though the trend is not significant. This study has confirmed that giving up smoking appears to reduce the frequency of chronic bronchitis symptoms very substantially and quickly. 
The Scottish Heart Health Study was funded by the Scottish Home and Health Department, and the smoking component by the Tobacco Products Research Trust. The opinions expressed are ours and not those of the funding bodies.

1 Burney PGJ, Holland WW. The epidemiology of respiratory disease in the UK. Medicine International 1982;1:B124-6. 2 World Health Organisation. World health statistics annual 1987. Geneva: WHO, 1987:342-9.

3 Beck GJ, Doyle CA, Schachter EN. A longitudinal study of respiratory health in a rural community. Am Rev Respir Dis 1982;125:375-81.

4 Kiernan KE, Colley JRT, Douglas JWB, Reid DD. Chronic cough in young adults in relation to smoking habits, childhood environment and chest illness. Respiration 1976;33:236-44.

5 Leeder SR, Colley JRT, Corkhill R, Holland WW. Changes in respiratory symptom prevalence in adults who alter their smoking habits. $J$ Epidemiol 1977;105:522-9.

6 Doll R, Peto R. Mortality in relation to smoking: 20 years' observations on male British doctors. Br Med J 1976;ii:1525-36.

7 Office of Population Censuses and Surveys. General household survey. London: HMSO, 1985:85.

8 Friedman GD, Siegelaub AB. Changes after quitting cigarette smoking. Circulation 1980;61:716-23.

9 Gulsvik A. Prevalence of respiratory symptoms in the city of Oslo. Scand J Respir Dis 1979;60:275-85.

10 Smith WCS, Crombie IK, Tavendale R, Irving JM, Kenicer $M B$, Tunstall-Pedoe $H$. The Scottish Heart Health Study: objectives and development of methods. Health Bull 1987;45:211-7.

11 Smith WCS, Tunstall-Pedoe $H$, Crombie IK, Tavendale $R$. Major risk factor and lifestyle findings from 10,359 men and women in the Scottish heart health study. Scot Med J 1989;34:550-5.

12 Florey C du V, Leeder SR. Methods for cohort studies of chronic airflow limitation. Copenhagen: World Health Organisation, 1982
13 Rose GA, Blackburn H, Gillum RF, Prineas RJ. Cardiovascular survey methods. Geneva: World Health Organization, 1982.

14 Irving JM, Clark EC, Crombie IK, Smith WCS. Evaluation of a portable measure of expired air carbon monoxide. Prev Med 1988;17:109-15.

15 Feyerabend C, Russell MAH. Rapid gas-liquid chromatographic determination of cotinine in biological fluids. Analyst 1980;105:998-1001.

16 Schlesselman JJ. Case-control studies. New York: Oxford University Press, 1982.

17 Armitage P, Berry G. Statistical methods in medical research. Oxford: Oxford University Press, 1987.

18 Holland WW, Ashford JR, Colley JRT, Crooke Morgan D, Pearson NJ. A comparison of two respiratory symptoms questionnaires. Bri J Prev Soc Med 1966;20:76-96.

19 Withey CH, Price CE, Swan AV, Papacosta AO, Hensley MJ. Repeatability of a questionnaire to assess respiratory symptoms in smokers. J Epidemiol Commun Health 1988;42:54-9.

20 Fletcher CM, Elmes PC, Fairbairn AS, Wood CH. The significance of respiratory symptoms and the diagnosis of chronic bronchitis in a working population. $B M J$ 1959;ii:257-66.

21 Hammond EC. Evidence on the effects of giving up cigarette smoking. Am J Publ Health 1965;55:682-91.

22 Wald N, Froggatt P. Nicotine, Smoking and the low tar programme. Oxford: Oxford University Press, 1989:59.

23 Higgins MW, Keller JB, Metzner HL. Smoking, socioeconomic status and chronic respiratory disease. Am Rev Respir Dis 1977;116:403-10.

24 Haenszel W, Hougen A. Prevalence of respiratory symptoms in Norway. J Chron Dis 1972;25:519-44.

25 Schenker MB, Samet JM, Speizer FE. Effect of cigarette tar content and smoking habits on respiratory symptoms in women. Am Rev Respir Dis 1982;125:684-90.

26 Densen PM, Jones EW, Bass HE, Breuer J. A survey of respiratory disease among New York City postal and transit workers. 1. Prevalence of symptoms. Environ Res transit workers.
1967; 2 : $265-86$.

27 Comstock GW, Brownlow WJ, Stone RW, Sartwell PE. Cigarette smoking and changes in respiratory findings. Arch Environ Health 1970;21:50-7. 